Bangladesh J. Bot. 49(4): 903-911, 2020 (December)

\title{
LEAF ANATOMICAL ADAPTATION OF EIGHTEEN MANGROVE PLANT SPECIES FROM THE SUNDARBANS IN BANGLADESH
}

\author{
Parveen Rashid, Kishwar Jahan Shethi* and Asfaque Ahmed
}

\author{
Department of Botany, University of Dhaka, Dhaka-1000, Bangladesh
}

Keywords: Leaf anatomy, Adaptation, Mangrove plant species

\begin{abstract}
Investigation on leaf anatomical adaptation of 18 mangrove plant species was carried out. Among the 18 species 13 were dorsiventral and five were isobilateral type. All the species had special stomatal structure and variable cuticle layer to minimize transpiration. Most of the species had succulent leaves with leaf thickness ranging from around 232 to $1363 \mu \mathrm{m}$. As an indication of salt secretion, both glandular and non-glandular trichomes were observed in several species. Although presence of single to multilayered hypodermis might effectively function as water storage tissue, several studied mangrove plant species e.g. Cynometra ramiflora L., Phoenix paludosa Roxb., Pongamea pinnata (L.) Pierre, Sonneratia apetala Buch. - Ham., S. caseolaris (L.) Engl. and Xylocarpus moluccensis (Lamk.) M. Roem. showed complete absence of hypodermis. This might be due to moderate saline condition. In addition, marked terminal tracheids in mesophyll tissue of a number of species might help with capillary water storage within the leaf. To enhance mechanical support several species were found to develop considerable amount of diverse sclereids within the mesophyll tissue and surrounding vascular bundle. Although maximum anatomical adaptations are common for plants growing in saline habitat it may be suggested that these features were differentially developed in plants specifically grown in mesohaline zone.
\end{abstract}

\section{Introduction}

A typical mangrove formation embraces an idiosyncratic assemblage of plant community, including shrubs and trees, dominating on low deltaic islands and sheltered estuaries where regular tidal influence of sea water prevails. These habitats are affected by humidity, precipitation, salinity, substrate and temperature. Plants are well adapted to the changing biological, chemical and physical traits of this environment through various xeromorphic properties including morphology, anatomy and physiology (Atkinson et al. 1967, Waisel 1972, Zimmermann 1983). Sundarban Mangrove Forests (SMF), the largest single tract mangrove forest of the world has the widest range of mangrove species in its tidal influenced saline soil. The SMF is located in the estuary of the River Ganges, in south-west coastal areas of Bangladesh and some part of West Bengal. The Sundarbans was originally extended about 40,000 sq, $\mathrm{km}$ but with continual agricultural and anthropogenic invasion the forest area reduced to a greater extent at around $16,000 \mathrm{sq} \mathrm{km}$ by 1930s (Blasco 1977). The Sundarbans is now restricted to around 10,000 sq km, stretching between the Baleshwar river, Bangladesh (about 60\%) and the Hooghly river, India (about 40\%) (Ahmed et al. 2018). Different saline zones, namely oligohaline, mesohaline and polyhaline occurs within SMF (Nazrul-Islam 2003) which is arbitrary depending on the seasons. Mesohaline zone is the comparatively moderate saline zone where both fresh water and saline water have influenced the plants whereas oligohaline zone is influenced mainly by fresh water and polyhaline zones have influence of the sea water. Such salinity gradients have been shown to influence species distribution and also the morphology of the plants (Maricle et al. 2009) and encompass a different kind of adaptive mechanism for those plants. The adaptive mechanisms of

*Author for correspondence: <kishwar.botany@du.ac.bd>. 
mangrove plants to the changing environment could be investigated through morphology, anatomy and physiology. Salinity has a direct influence on the leaf architecture of the plants (Chapman 1976). Leaves of mangrove habitat have evolved several distinctive characteristic features on cuticle, mesophyll zone, stomatal structure, hypodermis and vascular bundle of main vein which help them to photosynthesize optimally and serve a good vegetative growth under tidal influenced varied saline condition. Several studies have been conducted on the architecture, specially the micromorphology, of mangrove leaves from the Indian mangrove species (Seshavatharan and Srivalli 1989, Fitzgerald et al. 1992, Das and Ghose 1993, Ramassamy and Kannabiran 1996, Das 1999, Nabilah et al. 2011). At the same time, very little work (Malik and Bhosal 1983, Datta et al. 2007) have been done to demonstrate the influence of these highly variable habitats on the physiology of mangrove species. Recently in Bangladesh, some work have been done on species diversity and changes in forest and land cover (Nazrul-Islam 2003, Ahmed et al. 2018), effects of salinity on species diversity (Ahmed et al. 2011), soil properties (Ataullah et al. 2017) and heavy metals contamination (Ataullah et al. 2018). However, anatomical adaptation of members of gramineae e.g. Porteresia coarctata T. (Rashid and Sarker 2004), Myriostachya wightiana Hook. f. (Rashid and Ahmed 2011) growing in the coastal area of Bangladesh which are also available in the Sundarbans have been reported. Though the Sundarbans of Bangladesh have a wide variation of mangrove species no substantial information are available on the anatomy in relation to their adaptation. Therefore during the present investigation leaf anatomy of different species of mangrove plants in relation to the adaptive significance from mesohaline zone of Bangladesh SMF was carried out to have an idea of the combined effects of fresh water and saline water on the adaptation of these mangrove species. Such study will also enlighten the present existing knowledge on how to raise active vegetation on the vast newly accreted char in saline prone coastal areas of Bangladesh.

\section{Materials and Methods}

For anatomical study fresh leaves of 18 different mangrove species (Table 1) were collected in saturated polythene bags from different areas of mesohaline zone of Bangladesh Sundarbans (Fig. 1) and recorded by Ecology and Environment Laboratory, Department of Botany, University of Dhaka. Free hand sectioning of leaves were done at a position approximately half-way between the base and apex of a sector from one side of the lamina with the help of a razor blade. The sections were stained in safranin, mounted in $20 \%$ glycerol and studied with the help of a light microscope (Carl Zeiss Lab. A1 microscope). Microphotographs of the sections were taken using Axiocam ERc 5s digital camera attached with computer through Axio Vision Release 4.8.2 software. Measurements of important anatomical features, namely leaf thickness, cuticle thickness, epidermis diameter and hypodermis diameter were also estimated using stage micrometer and oculometer. An average of five random observations was taken from each plant species for each parameter and values were calculated for mean \pm standard error using the Microsoft Excel 2011. All anatomical studies were carried out in the Plant Physiology, Biochemistry and Plant Nutrition Laboratory, Department of Botany, University of Dhaka.

\section{Results and Discussion}

Eighteen species belonging to 11 different families of mangroves from the Sudarbans were studied. Out of 18 species the lamina of 13 were dorsiventral while in the rest five species, namely Pongamea pinnata L. Pierre. (Fig. 4D), Brownlowia tersa (L.) Kosterm., Phoenix paludosa Roxb. Sonneratia caseolaris (L.) Engl. and S. apetala Buch. - Ham. (Fig. 3F) the lamina were 
isobilateral. It is interesting to note that though Chapman (1976) on the basis of transverse section of leaves classified Excoecaria agallocha L. as isobilateral, it was found to be dorsiventral since mesophyll was demarcated into adaxial palisade parenchyma and abaxial spongy parenchyma. This observation is in conformity with the findings of Das and Ghose (1996).

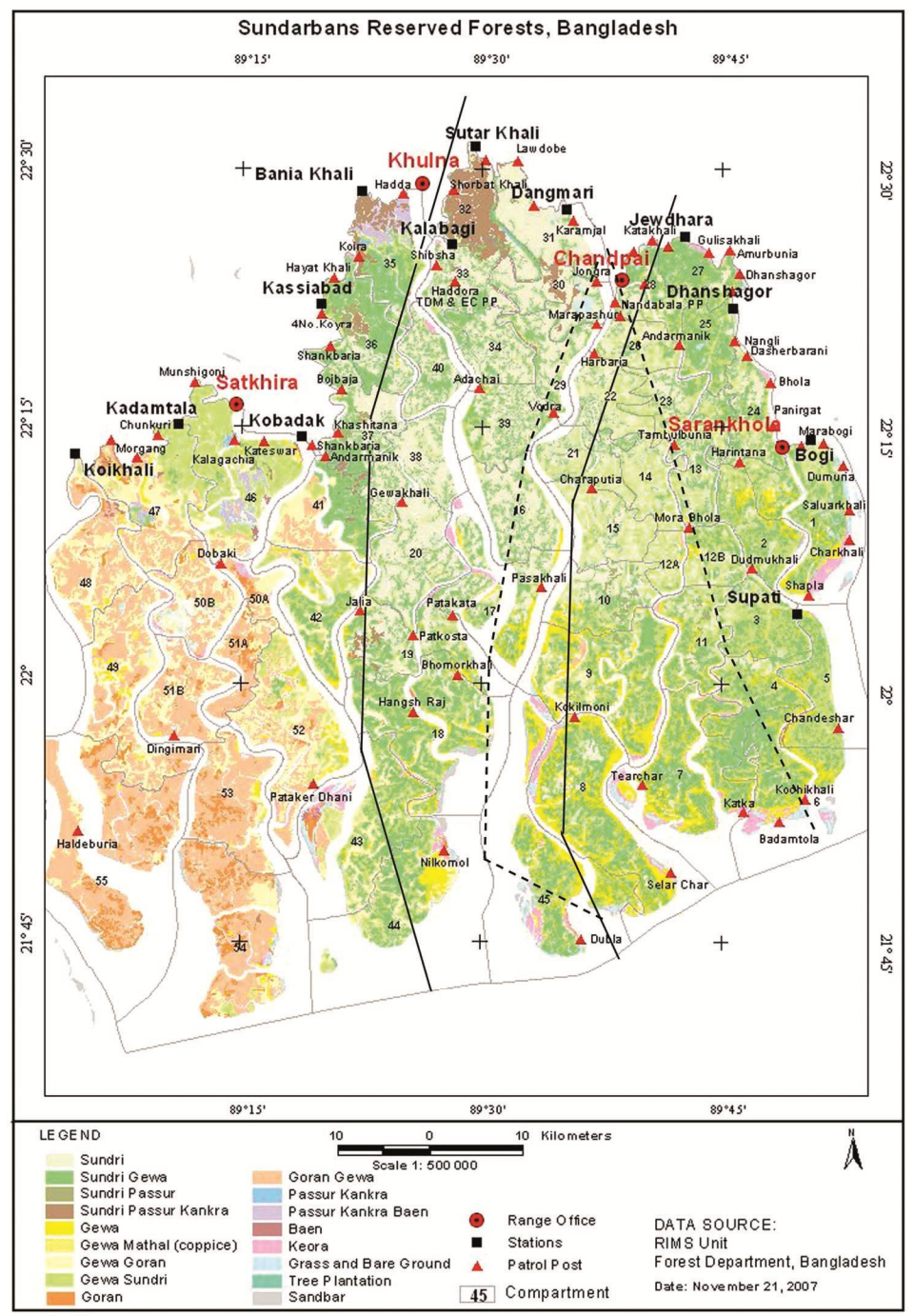

Fig. 1. Map showing the total area of Sundarban Mangrove Forests (SMF) where mesohaline zone demarcated by solid lines and oligo-mesohaline zone demarcated by dashed lines which becomes oligohaline during monsoon season and mesohaline during winter. Demarcation of the ecological zones was adopted from Nazrul-Islam (2003). Source of image: RIMS unit, Forest Department, Bangladesh

Two types of leaf hairs or trichomes, namely glandular and non-glandular were observed in the studied species. Glandular hairs were present on both adaxial and abaxial surfaces of Acanthus ilicifolius L. and only on adaxial surface of Aegiceros corniculatum Blanco. However, Das (1999) reported glandular hairs on both surfaces of A. corniculatum. Glandular type capitate hairs were visible on abaxial surface of Avicennia officinalis L. (Datta et al. 2007). Non-glandular hairs were 
followed on abaxial surfaces of A. ilicifolius while present on abaxial surface of Rhizophora apiculata Blume. Stellate hairs (non-glandular) were abundantly present on abaxial surface of Heritiera fomes Buch. - Ham. In Vitex trifolia L. hook shaped, multicellular, non-glandular hairs were found on abaxial and single-celled, non-glandular hairs on adaxial surface. The single-celled trichome could be a notable characteristic for $V$. trifolia, since it is general feature for root hair. Fig. 2A-H demonstrated different types of hairs studied. Hairs might be concerned with salt secretion, protection and therefore important in relation to adaptive nature. However, other studied materials displayed no such structure on their surfaces. Sunken stomata are another criterion of mangrove to minimize transpiration and they were observed in several samples e.g. A. ilicifolius (Fig. 2 I), A. corniculatum, Xylocarpus moluccensis (Lamk.) M. Roem., P. pinnata, P. paludosa. Guard cells have cuticular beak-like outgrowths on either the outer side or both outer and inner side of the stomatal pore in species like Bruguiera gymnorrhiza (L.) Lamk. Stomata are usually restricted to the abaxial surface of dorsiventral leaves and in isobilateral leaves are equally distributed on both surfaces except in P. paludosa where restricted to the abaxial surface only.

Maximum species have succulent leaves with higher leaf thickness and thin cuticle (Table 1). Maximum leaf thickness was observed in $S$. apetala $(1363.50 \pm 0.55 \mu \mathrm{m})$ followed by $S$. caseolaris $(939.30 \pm 0.34 \mu \mathrm{m})$. Considerable thin cuticle was found in $R$. apiculata $(23.04 \pm 0.56$ $\mu \mathrm{m})$, followed by $R$. mucronata Poir. $(10.24 \pm 0.45 \mu \mathrm{m})$ and A. corniculatum $(7.86 \pm 0.55 \mu \mathrm{m})$. Mangrove leaves are generally thick and succulent, which can be associated with the extra water storage capacity and leaf succulence of mangroves increases with the increase of substrate salinity (Wehe 1964). Thickness of cuticle may affect the exposure of thylakoid membranes to sunlight and thus controls the rate of carbon assimilation. Succulent and thick leaves with cutinized epidermis might help to prevent non-stomatal water loss (Das 1999) and regarded as an adaptive feature (Waisel 1972).

Colorless and larger cells beneath epidermis generally known as hypodermis were observed in most mangrove species which often function as water storage tissue (Das 1999). Single layer hypodermis was found in E. agallocha, two layer in R. mucronata, three layers in X. granatum and even five layers in A. officinalis (Fig. 3B, 3C, 3D and 3E). However, hypodermis was reported to be absent from several species studied here as in X. moluccensis (Fig. 3A), Cynometra ramiflora L., P. paludosa, P. pinnata, S. apetala and S. caseolaris. According to Zimmermann (1983) terminal tracheids helped with capillary water storage and provided mechanical support to the leaves. Naskar and Palit (2015) reported except in some species of Bruguiera all common mangrove genera show frequent development of groups of enlarged terminal tracheids at vein endings. During the present study, prominent terminal tracheids in the mesophyll of species, namely $S$. apetala, B. gymnorrhiza (Fig. 3F and 3G, respectively), E. agallocha, A. ilicifolius, $X$. moluccensis, A. officinalis, $P$. pinnata were noticed. Nonetheless, several anatomical characteristics to conserve water are mostly species specific and unique to mangrove plants as such characteristics are not found in their genetically close relatives (Naskar and Palit 2015).

Large number of xylem vessels in conspicuous vascular bundles serves for better production. A. ilicifolius carried three large vascular bundles in midrib and H. fomes had vascular bundle sheath extending upper and lower epidermis in lamina along with main vascular bundle. Structure of vascular bundles showed diversity across the studied species e.g. kidney shaped and closed in H. fomes, oval shaped in A. ilicifolius, lip shaped and open as in P. pinnata, S. caseolaris, fairy ring shaped in $R$. apiculata and cresent shaped in X. granatum (Fig. 4 F-K). Acrostrichum aureum L. collected species from Pteridaceae showed 5 - 6 circular, scatter vascular bundles in mid vein of frond (Fig. 4L). Vascular bundles of midrib region included one or sometimes two large metaxylem and a few protoxylem. Phloem elements were present on the abaxial side of 

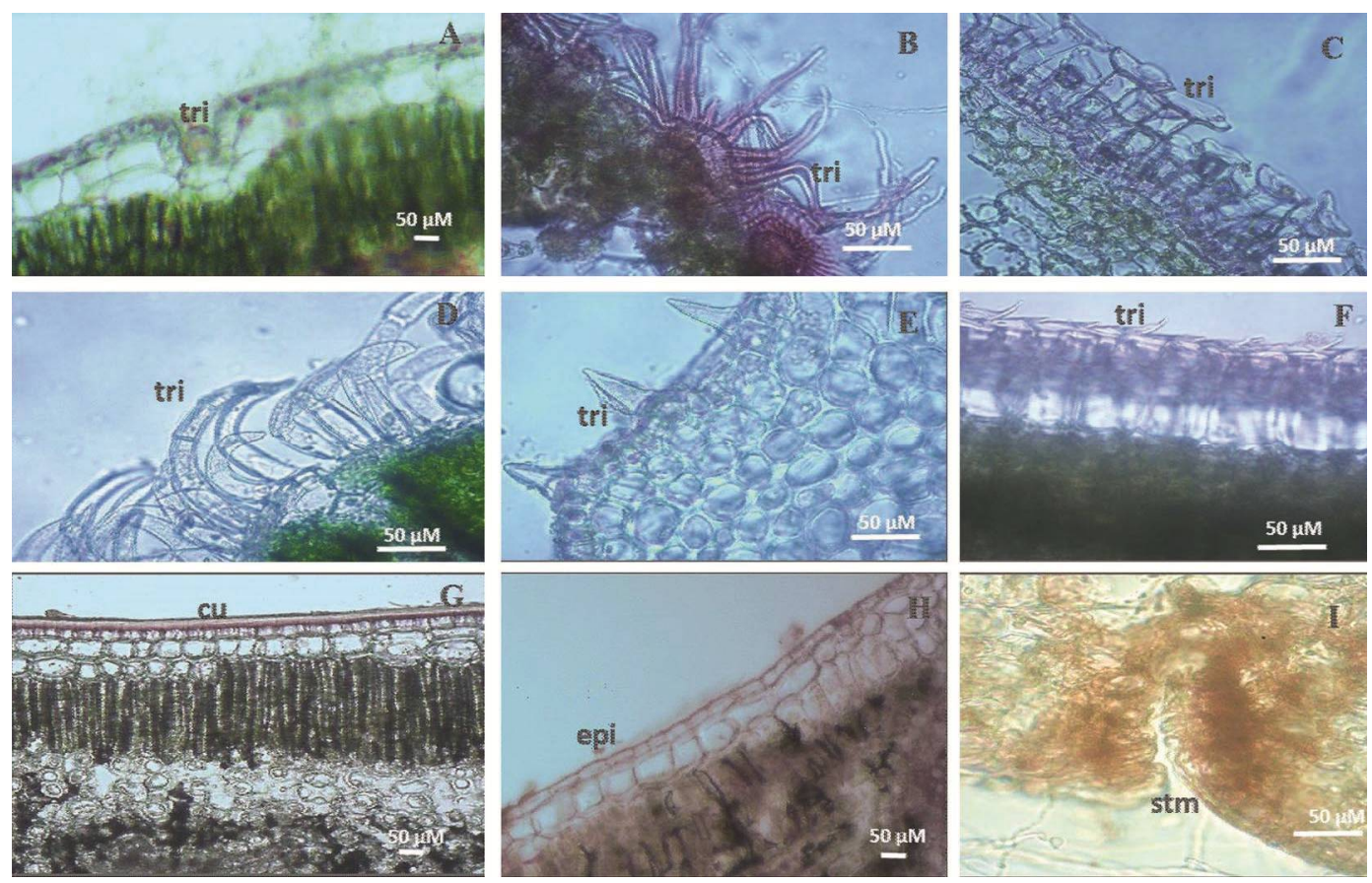

Fig. 2. Transverse sections of leaves showing various hairs (A) glandular in A. ilicifolius under 100X, (B) H. fomes with stellate, (C) A. officinalis with capitate, (D) and (E) multicellular and unicellular hairs respectively on V. trifolia, (F) papillary hair on X. moluccensis under 400X magnification; $(\mathrm{G})$ and $(\mathrm{H})$ presenting thick cuticle on $R$. mucronata and thin cuticle on $H$. fomes, respectively under 100X magnification; (I) sunken stomata on upper epidermis of $A$. ilicifolius under 400X magnification. Tri $=$ Trichome, $\mathrm{cu}=$ Cuticle, epi $=$ Epidermis and stm $=$ Stomata.
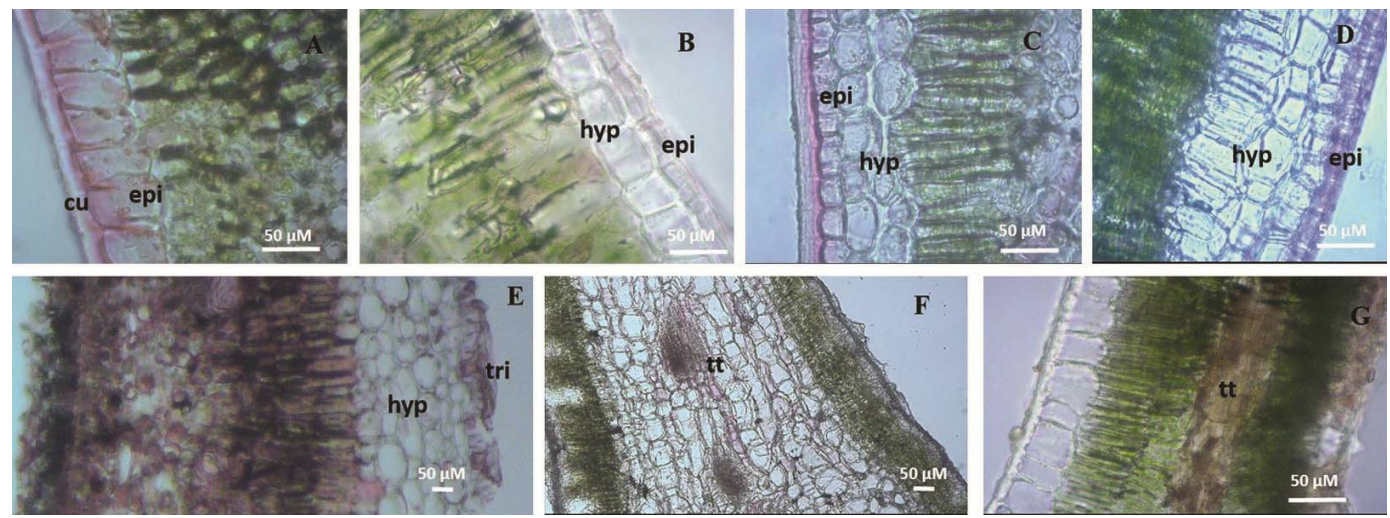

Fig. 3. Different layers of hypodermis beneath epidermal layer. (A) no hypodermis in X. moluccensis, (B) one layer in E. agallocha, (C) two layers in $R$. mucronata, (D) three layers in X. granatum under $400 \mathrm{X}$ and (E) five layers in A. officinalis under 100X magnification. Terminal tracheids in (F) S. apetala under 100X and (G) B. gymnorrhiza under $400 \mathrm{X}$ magnification. $\mathrm{Cu}=$ Cuticle, epi $=$ Epidermis, hy $=$ Hypodermis, tri $=$ Trichome and $\mathrm{tt}=$ Terminal tracheids. 
Table 1. Measurements of cuticle, epidermis, hypodermis and leaf thickness in case of studied materials in micrometer $(\mu \mathrm{m})$ based on average of five transverse sections from each material.

\begin{tabular}{|c|c|c|c|c|c|c|}
\hline $\begin{array}{l}\text { Scientific } \\
\text { name }\end{array}$ & $\begin{array}{l}\text { Family } \\
\text { name }\end{array}$ & LS & $\begin{array}{l}\text { Cuticle } \\
\text { thickness } \\
(\mu \mathrm{m})\end{array}$ & $\begin{array}{l}\text { Epidermis } \\
\text { diameter } \\
(\mu \mathrm{m})\end{array}$ & $\begin{array}{l}\text { Hypodermis } \\
\text { diameter } \\
(\mu \mathrm{m})\end{array}$ & $\begin{array}{l}\text { Leaf } \\
\text { thickness } \\
(\mu \mathrm{m})\end{array}$ \\
\hline Acanthus ilicifolius & Acanthaceae & $\mathrm{D}$ & $\begin{array}{l}\text { Thick } \\
5.12 \pm 0.14\end{array}$ & $25.60 \pm 0.78$ & $102.4 \pm 0.45$ & $575.70 \pm 0.57$ \\
\hline Acrostichum aureum & Pteridaceae & $\mathrm{D}$ & $\begin{array}{l}\text { Thin } \\
2.56 \pm 0.11\end{array}$ & $10.24 \pm 0.35$ & $30.72 \pm 0.11$ & $606.00 \pm 0.74$ \\
\hline Aegiceras corniculatum & Primulacase & $\mathrm{D}$ & $\begin{array}{l}\text { Very Thick } \\
7.68 \pm 0.55\end{array}$ & $17.92 \pm 0.35$ & $115.20 \pm 0.57$ & $404.00 \pm 0.57$ \\
\hline Avicennia officinalis & Acanthaceae & $\mathrm{D}$ & $\begin{array}{l}\text { Thick } \\
5.12 \pm 0.55\end{array}$ & $15.36 \pm 0.32$ & $120.32 \pm 0.82$ & $484.80 \pm 0.87$ \\
\hline Brownlowia tersa & Malvaceae & I & $\begin{array}{l}\text { Thin } \\
2.56 \pm 0.11\end{array}$ & $12.80 \pm 0.17$ & $20.48 \pm 0.57$ & $424.10 \pm 0.88$ \\
\hline Bruguiera gymnnorrhiza & Rhizophoraceae & $\mathrm{D}$ & $\begin{array}{l}\text { Thick } \\
5.12 \pm 0.57\end{array}$ & $17.92 \pm 0.20$ & $28.16 \pm 0.45$ & $474.10 \pm 1.02$ \\
\hline Cynometra ramiflora & Fabaceae & $\mathrm{D}$ & $\begin{array}{l}\text { Thin } \\
2.56 \pm 0.23\end{array}$ & $10.24 \pm 0.51$ & Absent & $303.00 \pm 0.87$ \\
\hline Excoecaria agallocha & Euphorbiaceae & $\mathrm{D}$ & $\begin{array}{l}\text { Thin and } \\
\text { Smooth } \\
2.56 \pm 0.23\end{array}$ & $20.48 \pm 0.75$ & $33.28 \pm 0.11$ & $474.70 \pm 0.57$ \\
\hline Heritiera fomes & Malvaceae & $\mathrm{D}$ & $\begin{array}{l}\text { Thin } \\
2.56 \pm 0.11\end{array}$ & $12.80 \pm 0.89$ & $51.20 \pm 0.57$ & $454.50 \pm 0.87$ \\
\hline Phoenix paludosa & Arecaceae & I & $\begin{array}{l}\text { Thin } \\
5.12 \pm 0.46\end{array}$ & $33.28 \pm 0.87$ & Absent & $232.30 \pm 0.57$ \\
\hline Pongamea pinnata & Fabaceae & I & $\begin{array}{l}\text { Thin } \\
2.56 \pm 0.12\end{array}$ & $20.48 \pm 0.51$ & Absent & $303.00 \pm 1.12$ \\
\hline Rhizophora apiculata & Rhizophoraceae & $\mathrm{D}$ & $\begin{array}{l}\text { Highly thick } \\
23.04 \pm 0.56\end{array}$ & $92.16 \pm 0.72$ & $76.80 \pm 0.11$ & $656.50 \pm 75$ \\
\hline Rhizophora mucronata & , & $\mathrm{D}$ & $\begin{array}{l}\text { Very Thick } \\
10.24 \pm 0.45\end{array}$ & $17.92 \pm 0.23$ & $38.40 \pm 0.23$ & $787.80 \pm 0.57$ \\
\hline Sonneratia apetala & Lythraceae & I & $\begin{array}{l}\text { Thin } \\
2.56 \pm 0.11\end{array}$ & $25.60 \pm 0.26$ & Absent & $\begin{array}{l}1363.50 \pm \\
0.55\end{array}$ \\
\hline Sonneratia caseolaris & , & I & $\begin{array}{l}\text { Thin } \\
2.56 \pm 0.23\end{array}$ & $10.24 \pm 0.11$ & Absent & $939.30 \pm 0.34$ \\
\hline Xylocarpus moluccensis & Meliaceae & $\mathrm{D}$ & $\begin{array}{l}\text { Thick } \\
7.68 \pm 0.43\end{array}$ & $71.68 \pm 0.12$ & Absent & $505.00 \pm 0.27$ \\
\hline Xylocarpus granatum & , & $\mathrm{D}$ & $\begin{array}{l}\text { Thin } \\
2.56 \pm 0.23\end{array}$ & $10.24 \pm 0.82$ & $94.72 \pm 0.55$ & $545.40 \pm 0.12$ \\
\hline Vitex trifolia & Lamiaceae & $\mathrm{D}$ & $\begin{array}{l}\text { Thin } \\
2.56 \pm 0.21\end{array}$ & $10.24 \pm 0.81$ & $51.20 \pm 0.12$ & $323.20 \pm 0.87$ \\
\hline
\end{tabular}

Mean value for five observations \pm standard deviation. $\mathrm{LS}=$ Leaf symmetry, $\mathrm{D}=$ Dorsiventral, $\mathrm{I}=$ Isobilateral. 
vascular bundle and separated from the xylem by parenchymatous cells. Ample of sclereids, fibres surrounding vascular bundles and mesophyll in species like $P$. pinnata, S. caseolaris, $R$. apiculata, X. granatum, A. aureum (Fig. 4H-L); presence of lacunae in A. corniculatum (Fig. 4C) reflected adaptive nature to stressful mangrove habitat. Sclereids are involved in capillary water storage as well as mechanical support for leaves with reduced turgor pressure (Tomlinson 1986). The coriaceous nature of studied mangrove leaves might be result of occurrence of such sclereids. It was interesting to note that though Heritiera fomes Buch. - Ham. is a well-known mangrove species it had several peculiar leaf characters e.g. loosely arranged palisade parenchyma, extended vascular bundles towards hypodermis and thin cuticle which indicate that this species is not so much suitable to withstand high saline habitat and commonly adapted to mesohaline zones.
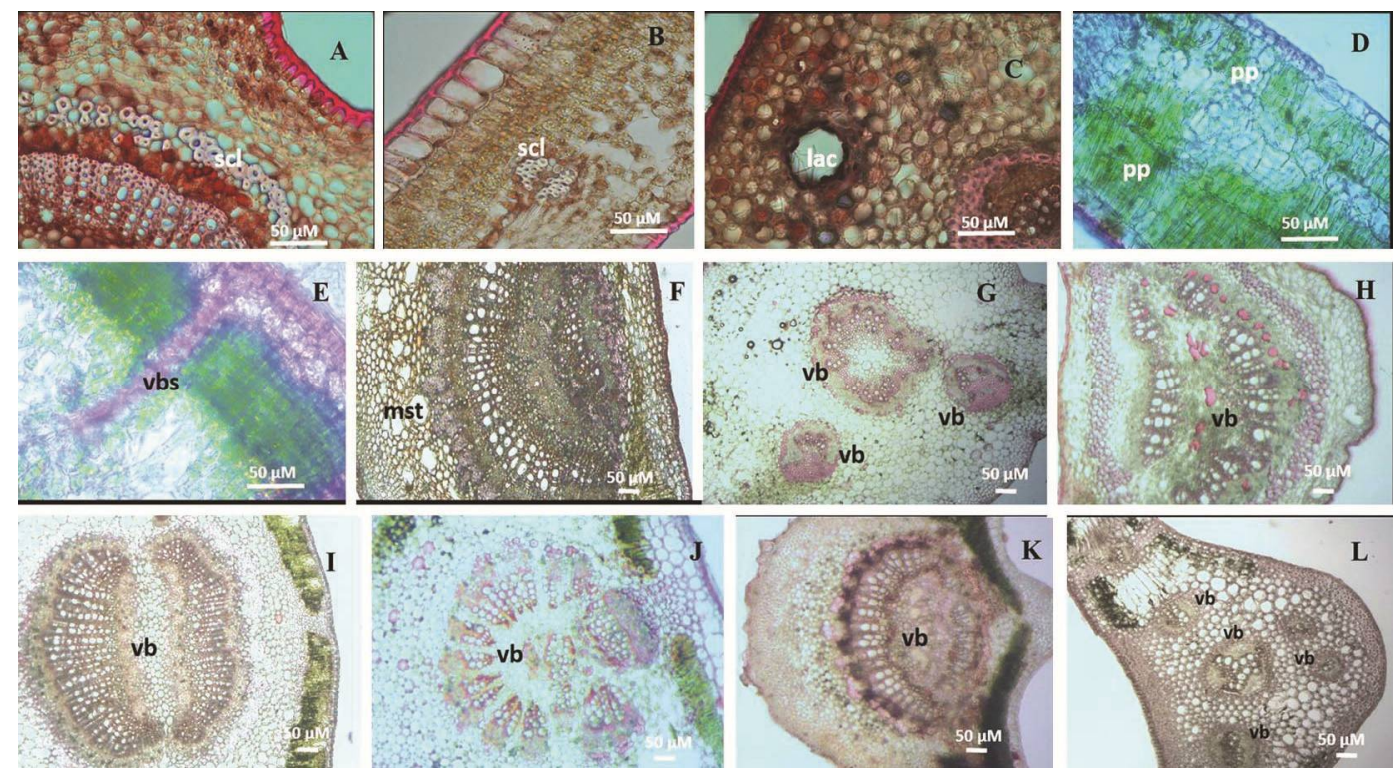

Fig. 4A and B. Sclereids in and around vascular bundle and in mesophyll of X. granatum respectively; C - lacuna in A. corniculatum; D - isobilateral leaf with two sided palisade parenchyma in P. pinnata; E - vascular bundle sheath extended up to both epidermal layer under 400X and (F) loosely arranged mesophyll tissue in H. fomes under 100X magnification. G - Three vascular bundles in A. ilicifolius; H - K. prominent vascular bundles with many xylem vessels and sclereids in $P$. pinnata, $S$. caseolaris, $R$. apiculata and X. granatum respectively and L - A. aureum collected only fern species under $100 \mathrm{X}$ magnification. $\mathrm{Scl}=$ Sclerenchyma, lac $=$ Lacuna, $\mathrm{pp}=$ Palisade parenchyma, $\mathrm{vbs}=$ Vascular bundle sheath, $\mathrm{vb}=$ Vascular bundle.

Considering the studied species from the present investigation it may be inferred that - 1 . Hair, cuticle, enlarged epidermal layer with succulent leaves helped to withstand variable and stressed mangrove habitat; 2. Hypodermis, terminal tracheid provided extra water storage and 3. For mechanical support prominent sclereids were found along with vascular bundles and within mesophyll tissue. Therefore, such typical characters of mangrove species of mesohaline zone might help to understand adaptation to the moderate saline environment and also have taxonomic value in genus differentiation. Besides, the study involving the plants grown under natural saline ecosystem is beneficial in understanding and managing salt stress tolerance (Lokhande and Suprasanna 2012). However, extensive study including anatomical, physiological and biochemical 
adaptation necessary for growth outlining mesohaline as well as other zones of saline environment will further facilitate the present understanding about plant-salt tolerance and adaptive ability.

\section{Acknowledgements}

The authors acknowledge the Ministry of Science and Technology, Government of the People's Republic of Bangladesh for financial support through Special Allocation for "Science and Technology Projects".

\section{References}

Ahmed A, Ataullah M, Rashid P, Paul AR, Dutta S and Ali MS 2018. Species diversity, change in forest cover and area of the Sundarbans, Bangladesh. Bangladesh J. Bot. 47(3): 351-360.

Ahmed A, Aziz A, Khan AZMNA, Islam MN, Iqbal KF, Nazma and Islam MS 2011. Tree diversity as affected by salinity in the Sundarbans Mangrove Forests, Bangladesh. Bangladesh J. Bot. 40(2): 197-202.

Ataullah M, Chowdhury MMR, Hoque S and Ahmed A 2017. Physico-chemical properties of soils and ecological zonations of soil habitats of Sundarbans of Bangladesh. International J. Pure and Applied Researches 1(1): 80-93.

Ataullah M, Hoque S, Rashid P and Ahmed A 2018. Spatial variation and contamination levels of different metals of soils of Bangladesh Sundarbans. Indian Forester 144(5): 412-423.

Atkinson MR, Findlay GR Hope AB, Pitman MG, Saddler HDW and West KR 1967. Salt regulation in the mangrove Rhizophora mucronata Laim. and Aegialitis annulata R. Br. Aust. J. Biol. Sci. 20: 589-599.

Blasco F 1977. Outlines of ecology, botany and forestry of the mangals of the Indian subcontinent. In: Wet Coastal Ecosystems. Chapman VJ (Eds.). Elsevier, Amsterdam. pp. 241-260.

Chapman VJ 1976. Mangrove vegetation. J. Cramer, Vaduz, Germany. p. 474.

Das S 1999. Adaptive feature of some mangroves of Sundarbans, West Bengal. J. Plant Biol. 42(2): 109-116.

Das S and Ghose M 1993. Morphology of stomata and leaf hairs of some halophytes from Sundarbans, West Bengal. Phytomorph. 43: 59-70.

Das S and Ghose M 1996. Anatomy of leaves of some mangroves and their associates of Sundarbans, West Bengal. Phytomorph. 46: 139-150.

Datta PN, Das S, Ghose M and Spooner-Hart R 2007. Effects of salinity on photosynthesis, leaf anatomy, ion accumulation and photosynthetic nitrogen use efficiency in five Indian mangroves. Wetlands Ecol. Manage. 15: 347-357.

Fitzgerald MA, Orlovich DA and Allaway WG 1992. Evidence that abaxial leaf glands are the sites of salt secretion in leaves of the mangrove Avicennia marina (Forsk.) Vierh. New Phytol. 120: 1-7.

Lokhande V and Suprasanna P 2012. Prospects of halophytes in understanding and managing abiotic stress tolerance. In: Environmental adaptations and stress tolerance of plants in the era of climate change, Ahmad P and Prasad MNV (Eds), Springer, Berlin, pp. 29-56.

Malik NG and Bhosale LJ 1983. Leaf anatomy and its relation to physiology of leaf in mangroves. Proc. National Symposium on Advancing Frontiers of Plant Sciences, Jodhpur, India. pp. 248-249.

Maricle BR, Koteyeva NK, Voznesenskaya EV, Thomasson JR and Edwards GE 2009. Diversity in leaf anatomy, and stomatal distribution and conductance, between salt marsh and freshwater species in the $\mathrm{C}_{4}$ genus Spartina (Poaceae). New Phytol. 184: 216-233.

Nabilah M, Nurnida MK, Noraini T, Ruzi AR, Nurshahidah AB, Amalin MR and Mohd-Arrabe 2011. Leaf anatomical adaptation of some mangrove species (Rhizophoraceae). Proc. 10th Int. Ann. Symp. UMTAS.

Naskar S and Palit PK 2015. Anatomical and physiological adaptations of mangroves. Wetlands Ecol. Manage. 23(3): 357-370. 
Nazrul-Islam AKM 2003. Mangrove Forest Ecology of Sundarbans: The study of change in water, soil and plant diversity In: Sustainable Environment: A statistical Analysis, Ghosh AK, Ghosh JK and Mukhopadhaya MK (Eds), Oxford University Press, New Delhi. pp. 126-147.

Ramassamy V and Kannabiran B 1996. Leaf anatomy and taxonomy in Rhizophoraceae. Indian For. 122: 1049-1061.

Rashid P and Ahmed A 2011. Anatomical adaptations of Myriostachya wightiana Hook. f. to salt stress. Dhaka Univ. J. Biol. Sci. 20(2): 205-208.

Rashid P and Sarker BC 2004. Comparative study of leaf anatomy of Porteresia coarctata T. and Oryza sativa L. Dhaka Univ. J. Biol. Sci. 13(2): 137-140.

Seshavatharan V and Srivalli M 1989. Systematic leaf anatomy of some Indian mangroves. Proc. Ind. Acad. Sci. (Plant Sci.) 99:557-565.

Tomlinson PB 1986. The Botany of Mangroves. Cambridge University Press, New York, p. 443.

Waisel Y 1972. Biology of Halophytes. Academic Press, New York. p. 410.

Wehe V 1964. Beitrage zur Okologie der mittle und west-europaischen Salzgetation (Gezeitenkusten). I Biet. Biol. Pflanzen. 39: 189-237.

Zimmermann MH 1983. Xylem structure and the ascent of sap. Springer-Verlag, Berlin. p. 143. 